\title{
KAJIAN KREDIT MELALUI PERENCANAAN DAN PENGENDALIANNYA KASUS PADA PT. BANK PERKREDITAN RAKYAT BATANG TARUSAN
}

\author{
Riri Mayliza \\ Sekolah Tinggi Ilmu Ekonomi “KBP” Padang \\ ririmayliza@akbpstie.ac.id
}

\begin{abstract}
ABSTRAK
Penelitian ini bertujuan untuk mengetahui perencanaan dan pengendalian kredit usaha kecil yang dilakukan oleh PT. BPR Batang Tarusan. Teknik pengumpulan data yang digunakan dalam penelitian ini adalah penelitian lapangan dengan cara melakukan penelitian langsung ke PT. BPR Batang Tarusan untuk mengumpulkan data yang mendukung penelitian ini serta penelitian perpustakaan dengan cara mempelajari bukubuku dan literature yang ada kaitannya dengan penelitian ini. Teknik analisis data adalah analisis secara deskriptif kualitatif. Dari hasil analisis diperoleh bahwa perencanaan kredit untuk skala kecil pada PT. BPR Batang Tarusan yaitu dalam bentuk KUK dilakukan dengan cara mempertimbangkan aspek-aspek kondisi perekonomian dan perdagangan, line of business, keadaan nasabah, keadaan keuangan bank, serta organisasi bank dan skill karyawan bagian kredit.
\end{abstract}

Kata Kunci: Perencanaan Dan Pengendalian Kredit

\section{PENDAHULUAN}

Dalam perkembangan perekonomian masyarakat Indonesia umumnya banyak menemukan permasalahan. Permasalahan yang menonjol adalah masalah permodalan. Untuk mengantisipasi permasalahan tersebut berbagai upaya telah dilakukan, diantaranya adalah dengan mengusahakan pengembangan industri kecil melalui sistem bapak angkat dan usaha peningkatan perkoperasian yang merupakan urat nadi perekonomian rakyat serta pemberian kredit kepada masyarakat melalui badan kecil berupa bank atau lembaga keuangan non bank.

PT. Bank Perkreditan Rakyat Batang Tarusan, sebagai salah satu bank yang menyalurkan dana dengan memberikan fasilitas kredit yang bertujuan mambantu masyarakat dalam hal permodalan dengan memberikan kredit dan untuk mencapai tujuan tersebut diperlukan perencanaan dan pengendalian atas semua kegiatan termaksud terhadap pemberian kredit.

Berikut ini data tentang kualitas pemberian kredit yang diberikan oleh PT. Bank Perkreditan Rakyat Batang Tarusan tahun 2007 - 2010 :

Tabel 1

Pemberian Kredit Menurut Sektor Ekonomi Tahun 2007 - 2010 (dalam ribuan rupiah)

\begin{tabular}{|l|l|l|l|l|} 
Sektor & 2007 & 2008 & 2009 & 2010
\end{tabular}




\begin{tabular}{|c|c|c|c|c|}
\hline Pertanian & 7.250 & 2.750 & - & - \\
Perindustrian & - & - & - & - \\
Perdagangan & 1.351 .874 & 1.401 .387 & 1.828 .190 & 1.966 .064 \\
Jasa-jasa & 37.413 & 10.367 & 5.931 & - \\
Lain-Lain & 2.401 .800 & 3.184 .920 & 3.899 .287 & 4.242 .901 \\
\hline Total & $\mathbf{3 . 7 9 8 . 3 3 7}$ & $\mathbf{4 . 5 9 9 . 4 2 3}$ & $\mathbf{5 . 7 3 3 . 4 0 8}$ & $\mathbf{6 . 2 0 8 . 9 6 5}$ \\
\hline
\end{tabular}

Sumber : PT. BPR Batang Tarusan

Dari tabel 1. terlihat bahwa perkembangan pemberian kredit berdasarkan sector dari tahun 2007-2010 yang dominan yaitu terletak pada sector lain-lain yaitu dari Rp. 2.401.800,- meningkat menjadi Rp. 4.242.901,- dan sector perdagangan dari tahun 2007-2010 dari Rp. 1.351.874,-- meningkat menjadi Rp. 1.966.064,-- sedangkan sector pertanian, perindustrian dan jasa-jasa lain tidakmengalami perubahan yang signifikan

Tabel 2

Kualitas Kredit Yang diberikan (dalam ribuan rupiah)

\begin{tabular}{|l|c|c|c|c|}
\hline Keterangan & $\mathbf{2 0 0 7}$ & $\mathbf{2 0 0 8}$ & $\mathbf{2 0 0 9}$ & $\mathbf{2 0 1 0}$ \\
\hline Lancar & 3.710 .952 & 4.416 .331 & 5.512 .746 & 5.688 .804 \\
Kurang Lancar & 39.677 & 81.778 & 108.991 & 41.092 \\
Diragukan & 36.098 & 73.840 & 64.214 & 95.511 \\
Macet & 11.610 & 27.465 & 47.457 & 383.558 \\
\hline \multicolumn{1}{|c|}{ Total } & $\mathbf{3 . 7 9 8 . 3 3 7}$ & $\mathbf{4 . 5 9 9 . 4 2 4}$ & $\mathbf{5 . 7 3 3 . 4 0 8}$ & $\mathbf{6 . 2 0 8 . 9 6 5}$ \\
\hline
\end{tabular}

Sumber; PT. BPR Batang Tarusan

Berdasarkan pada tabel 2 diatas terlihat bahwasanya perkembangan jumlah kualitas kredit yang diberikan oleh PT. Bank Perkreditan Rakyat Batang Tarusan dari tahun 2007-2010, kredit lancar dari tahun ke tahun mengalami kenaikan yang cukup baik yaitu dari Rp. 3.710.952,- meningkat menjadi Rp. 5.688.804,- untuk kredit kurang lancar dari tahun 2007-2010 mengalami peningkatan dari Rp. 39.677,- menjadi Rp. 41.092,- dan untuk kredit diragukan juga mengalami peningkatan dari Rp. 36.098,mejadi Rp. 95.511,- sedangkan untuk kredit macet juga mengalami peningkatan namun tidak terlalu berpengaruh.

\section{TINJAUAN PUSTAKA}

Kredit memiliki arti yang beraneka-ragam, sesuai dengan bidang ilmu yang menggunakan kata tersebut. Kredit berasal dari bahasa Yunani "credere" yang berarti "kepercayaan" atau dalam bahasa Latin " creditum" yang berarti "kepercayaan atau kebenaran".

Dalam Undang-Undang Perbankan No. 7 tahun 1992, yang telah diubah dengan Undang-Undang No. 10 tahun 1998 tentang ketentuan umum, pengertian kata kredit adalah :

"Kerdit adalah penyedian uang tagihan yang dapat dipersamakan dengan itu, berdasarkan kesepakatan atau persetujuan pinjam-meminjam antara bank dengan pihak lain yang mewajibkan pihak peminjam untuk melunasi hutangnya setelah jangka waktu tertentu dengan pemberian harga atau pembagian hasil keuntungannya".

Adanya beberapa dasar yang digunakan untuk membagi klasifikasi dari kredit, (Tjoekam dkk, 1996) yaitu : 
1. Berdasarkan Tujuannya

a. Kredit konsumtif, yaitu kredit yang diberikan dengan tujuan untuk membiayai kebutuhan yang bersifat konsumtif seperti untuk membeli kendaraan yang dipakai, peralatan rumah tangga dan lain sebagainya.

b. Kredit produktif, yaitu kredit yang bertujuan memperlancar proses produksi. Kredit ini digunakan sebagai penambahan modal baik untuk investasi maupun modal kerja bagi pemberi kredit.

2. Berdasarkan Jangka Waktu

a. Short team credit, kredit jangka pendek yang memiliki jangka waktu maksimal satu tahun.

b. Intermediate credit, merupakan kredit jangka menengah yang memiliki jangka waktu antara $1-5$ tahun

c. Long team credit, merupakan kredit jangka panjang yang memiliki jangka waktu diatas 5 tahun.

3. Berdasarkan Cara Pemakaian

a. Kredit rekening Koran bebas, debitur menerima seluruh kreditnya dalam bentuk rekening dan kepadanya diberikan blanko cek dan rekening Koran. Peminjamannya diisi menurut besarnya kredit yang diberikan. Debitur bebas melakukan penarikan terhadapa rekening yang bersangkutan selama kredit berjalan.

b. Kredit rekening Koran terbatas, dalam kredit ini dilakukan pembatasan bagi kreditur dalam penarikan dana melalui rekeningnya. Debitur tidak diperkenankan menarik dana secara sekaligus, tetapi secara teratur dan sesuai dengan kebutuhan yang diperkenankan.

c. Kredit rekening Koran afloped, dalam kredit ini penarikan dapat dilakukan secara sekaligus dalam arti kata seluruh maksimal kredit pada waktu penarikan sebelumnya telah sepenuhnya dipergunakan oleh debitur

d. Revolving credit, system penarikanya sama dengan cara pada rekening Koran bebas dengan masa penggunaanya satu tahun tetapi cara pemakainanya berbeda.

e. Team loan, sistemnya sama dengan rekening Koran bebas namun lebih fleksibel karena debitur dapat dengan bebas menggunakan uang kreditnya untuk keperluan apa saja seseuai dengan kebutuhan usahanya.

4. Berdasarkan Sumber Dana Kredit

a. Kredit perioritas, kredit ini memiliki tingkat suku bunga rendah khususnya diperuntukan untuk pengusaha pribumi golongan ekonomi rendah atau lemah guna membiayai usaha yang akan memiliki peranan penting dalam mensukseskan program pemerintah. Kredit ini sebagaian besar dibiayai dengan dana bank Indonesia yang disalurkan kepada bank pemberi kredit melalui bantuan dana likuidasi bank Indonesia.

b. Kredit non perioritas, kredit ini merupakan kredit yang dibiayai sendiri oleh bank pelaksana pemberi kredit. Tingkat bunga ditentukan melalui mekanisme pasar perbankan. Kredit non perioritas umumnya diperlukan bagi pengusaha golongan kuat.

5. Berdasarkan Jaminan

a. Kredit tanpa jaminan, di Indonesia kredit ini sudah banyak digunakan.

b. Kredit dengan jaminan, disamping itu penilaian terhadap prospek usaha nasabah yang dapat dilihat dari laporan keuanganya. 
6. Berdasarkan Jaminan Kredit

a. Kredit modal kerja, adalah kredit yang diberikan untuk mmbiayai kebutuhan modal kerja yang dibutuhkan.

b. Kredit investasi, adalah kredit untuk pembelian barang modal dan jasa yang diperlukan guna rehabilitas, modernisasi, ekspansi dan renovasi proyek dan pendirian usaha baru.

c. Kredit konsumsi, adalah kredit yang diberikan kepada pihak ketiga termaksud pegawai bank untuk keperluan komsumsi dengan cara membeli, menyewa atau dengan cara lain misalnya KPR, KPG (Sepeda Motor), dan kredit ruko.

Pada dasarnya perencanaan dapat diartikan sebagai suatu kegiatan dalam menetapkan tindakan-tindakan yang akan dilakukan dalam melaksanakan suatu aktifitas dalam rangka pencapaian suatu tujuan. Hal ini dapat dilihat dari beberapa pengertian tentang perencanaan yang dikemukan oleh para ahli.

Horgen (1997) mengemukan bahwa perencanaan adalah "the selecting of objectives and the means for theif attainment".Sedangkan menurut James Dwilson B Campbell perencanaan adalah "acotinuous process of determining the event and the actives assential of state gold”. Sementara itu menurut Horrold Koontz dan Cryill O Donnel mengatakan bahwa perencanaan adalah "the function of manager which in volves the selection form among alternative, police, procedure and program".

Banyak manfaat yang diperoleh dari penyusunan perencnaan seperti apa yang dikemukan oleh Handoko (1996), diantaranya adalah :

1. Dengan adanya perencanaan menyebabkan aktivitas-aktivitas yang dilakukan secara teratur dengan tujuan tertentu.

2. Perencanaan mempunyai perencanaan pokok untuk fungsi-fungsi lainnya terutama fungsi pengawasan.

3. Perencanaan menyebabkan pekerjaan yang tidak produktif dapat diperkecil ataupun dihilangkan.

4. Perencanaan dapat menjadi suatu alat pengukur hasil-hasil yang dicapai.

5. Membantu menetapkan taggung jawab lebih cepat.

6. Menghemat waktu dan dana.

Menurut Tjoekam (1999), mengemukan bahwa perencanaan kredit adalah :

"Suatu proses logis dan penentuan variable dan peristiwa-peristiwa yang terdokumentir, baik masa silam (past), maupun masa dating (future), yang akan mempengaruhi operasional perkreditan dalam mencapai tujuan yang telah ditentukan (target market)".

Ditambah juga oleh Tjoekam (1999), mengenai penilaian tentang jaminan pemberian kredit berdasarkan Principles 5C:

1. Character

Untuk lebih mengetahui sifat-sifat dari calon debitur sebagai manajemen atau pemilik perusahaan, bank melakukan survey, study, dan riset terhadap tingkah laku, terutama sikap atau tingkah laku mengenai kemauan dan tanggung jawab atas setiap kewajiban yang diperjanjikan.

2. Capacity

Yang dimaksud dengan capacity atau kapasitas disini adalah gambaran mengenai kemampuan debitur untuk memenuhi kewajiban-kewajibannya, kemampuan debitur untuk mencari dan mengkombinasikan resources yang terkait dalam bidang usaha, kemampuan memproduksi barang dan jasa dapat memenuhi kebutuhan konsumuen atau pasar. 
3. Capital

Penilaian pada aspek ini diarahkan pada kondisi keuangan nasabah, yang terdiri dari current asset yang tertanam dalam bidang bisnis dikurangi current liabilities disebut working capital dan modal yang tertanam pada barang-barang long asset dikurangi long term financing .

4. Collateral

Collateral adalah jaminan kredit yang mempertinggi tingkat keyakinan bank bahwa debitur dengan bisnisnya mampu melunasi kredit, dimana agunan merupakan jaminan tambahan jika bank menganggap aspek-aspek yang mendukung usaha debitur lemah.

5. Condition

Kondisi yang diharapkan adalah bahwa kegiatan usaha debitur mampu mengikuti fluktasi ekonomi baik dalam negri mupun luar negri, dan usaha masih mempunyai prospek kedepan selama kredit masih dinikmati oleh debitur. Jika dapat, lebih dari tiga tahun kedepan kegiatan bidang usaha masih layak di prospektif.

Dalam penyusunan perencanaan kredit, ada beberapa faktor yang akan terlibat dan perlu dipertimbangkan antara lainnya (Menurut Muljono, 1990) :

1. Kegiatan ekonomi secara makro

2. Pasar modal yang dapat menampung dana (kredit) yang ditawarkan kepada debiur atau masyarakat

3. Kemampuan organisasi dan manajemen dari bank yang bersangkutan

4. Kemampuan bank dalam memperoleh sumber-sumber dana dengan biaya yang rasional

5. Situasi politik suatu Negara

6. Peraturan-peraturan moneter yang berlaku, terutama mengenai tingkat bunga.

7. Berbagai macam dari sumber dana yang dipasarkan masyarakat, mekanisme dan sasaran pemasaran yang ada dalam masyarakat.

Pengendalian didefenisikan oleh Manulang (1985) sebagai berikut :

"Pengendalian adalah suatu proses menetapkan pekerjaan apa yang sudah dilaksanakan, menilainya dan mengoreksinya bila perlu dengan maksud supaya pelaksanaan kegiatan sesuai dengan rencana”.

Menurut Moldjono (1994), pengendalian kredit merupakan :

"Salah satu tugas manajemen dalam usahanya untuk penjagaan dan pengamanan serta pengelolahan kekayaan dalam bentuk perkreditan yang lebih baik dan efesien, guna menghindari terjadinya penyimpangan-penyimpangan dengan cara mendorong dipatuhinya kebijaksanaan-kebijaksanaan perkreditan yang telah ditetapkan serta mengusahakan penyusunan administrasi perkreditan yang benar".

Tindakan prefentif dalam pengendalian kredit ini berupa tindakan berjaga-jaga agar kemungkinan terjadinya penyelewengan yang mengakibatkan terjadinya kredit macet dapat diperkecil.

Tindakan-tindakan tersebut dapat dibedakan sebagai berikut :

1. Pengendalian Intern Bank

a. Pengawasan terhadap karyawan-karyawan yang terlibat dalam pemberian kredit

b. Pengawasan terhadap administrasi bank yang berkaitan dengan pencatatan peran aksi perkreditan 
2. Pengendalian Terhadap Nasabah

a. Melakukan analisa yang tepat terhadap nasabah baik masalah bidang usaha maupun keuangan perusahaan nasabah

b. Pengawasan fisik terhadap aktivitas nasabah untuk mencek kebenaran dari keseluruhan keterangan data atau laporan nasabah dibandingkan dengan jumlah dan keadaan secara fisik, juga untuk melihat secara langsung keadaan usaha dan mewawancarai atau diskusi dengan nasabah

\section{Tindakan Refrensif}

Tindakan ini ditujukan untuk melakukan tindakan perbaikan terhadap penyimpangan atau penyelewengan yang terjadi. Tindakann refrensif dapat dijadikan dua bentuk (menurut Mulyono, 1993) :

1. Pengendalian Intern Bank

a. Penyelesaian administratif, yaitu tindakan penerbitan administrasi bank yang disebabkan adanya penyelewengan oleh pegawai bank. Tindakan ini dilakukan untuk mengetahui berapa besar kerugian yang ditimbulkan, kemungkinan terlibatnya pihak-pihak luar bank dan untuk menyusun analisa perbaikan system dan prosedur serta untuk melakukan penyelamatan terhadap posisi bank bila adanya kemungkinan terjadinya tuntutan dari pihak luar bank.

b. Tindakan terhadap diri pelaku, tindakan ini dilakukan seperti mengirim surat teguran, surat peringatan, atau bila kesalahan yang dilakukan sudah sangat berat, pelaku dapat diberitahukan secara tidak hormat, atau dapat dituntut kepengadilan sebagai pelaku tindak pidana.

2. Pengendalian Terhadap Nasabah

Workout, yaitu kerja sama yang dilakukan bank dan nasabah melakukan persiapan kerangka kerja dalam penyelesaian kredit bermasalah, tanpa melakukan penyitaan, aksi hukum atau tuntutan pailit. Sehubungan dengan hal ini bank dapat memberikan suntikan dana dengan harapan nasabah dapat membayar kembali kewajibankewajibannya dan pihak bank dapat memperoleh pembayaran kembali.

3. Pencairan Jaminan (Collateral Liquidation)

Adalah tindakan pemaksaan yang oleh bank untuk melakukan penjualan sendiri dengan pengawasan pihak bank atau melalui pihak ketiga atau kantor lelang.

4. Tuntunan Hukum atau Mengajukan Pailit Melalui Lembaga Peradilan Cara ini merupakan cara terakhir yang dilakukan jika upaya pertama dan kedua belum mencapai hasil yang maksimal seperti yang diharapkan oleh pihak bank. Cara ini jarang dilakukan karena membutuhkan biaya dan waktu yang cukup lama, sedangkan hasilnya belum dapat diramalkan. Tercapainya serta melakukan tindakan perbaikan jika ditemui penyimpangan-penyimpangan.

Pengendalian didefenisikan dengan berbagai istilah dalam organisasi yaitu :

1. Strategi, suatu rencana tindakan jangka panjang yang luas dan sifatnya umum.

2. Kebijakan (policy), sekumpulan aturan luas yang menuntut dan mengarahkan tindakan-tindakan dalam organisasi.

3. Pemprogramanan, pengembangan dan pemilihan seperangkat program yang dilaksanakan.

4. Pengendalian mengarahkan seperangkat variabel kearah tercapainya sasaran dan tujuan.

5. Pengendalian manajemen, semua metode yang digunakan oleh manajemen untuk menjamin terlaksananya program sesuai dengan strategi. 
6. Sistem pengendalian manajemen, struktur dan proses sistematis yang digunakan oleh manajemen dalam pengendalian

Ada tiga tahap pada proses pengendalian ini yaitunya tindakan perencanaan (planning action), pelaksanaan tindakan (execution action), dan evaluasi tindakan (evaluation ofaction), yang terjadi sebelumnya, selama dan sesudah sesuatu tindakan atau kejadikan. Ketiga tahap ini dilaksanakan diseluruh tingkat dalam organisasi, dari manajemen puncak sampai unit operasi terkecil. Pengendalian yang dilakukan dalam organisasi dapat mempercepat proses ketidakberesan dan memperbaiki kesalahankesalahan atau penyelewengan sumber daya.

\section{METODE PENELITIAN}

\section{Jenis Penelitian}

Metode penelitian ini bersifat deskriptif yaitu dengan cara melihat dan mengumpulkan data serta melaporkan asil pengamatan tersebut.

\section{Objek Penelitian}

Objek dalam penelitian ini adalah PT. Bank Perkreditan Rakyat Batang Tarusan yang melakukan kegiatan usahanya di Barung-Barung Balantai Kabupaten Pesisir Selatan.

\section{Teknik Pengumpulan Data}

Teknik pengumpulan data yang digunakan oleh penulis adalah riset perpustakaan dan riset lapangan :

1. Riset Perpustakaan (Library Research)

Riset ini dilakukan dengan mengumpulkan data, menggunakan teori-teori yang berkaitan dengan masalah-masalah yang akan dibahas, yang diperoleh dari literatur yang ada baik berupa buku-buku, majalah-majalah yang berkaitan dengan masalah yang akan diteliti.

2. Riset Lapangan (Field Research)

Riset ini dilakukan dengan pengumpulan data-data dari PT. Bank Perkreditan Rakyat Batang Tarusan dengan melakukan wawancara langsung dengan pihak bank yang bertujuan untuk mendapatkan data dari perusahaan tersebut.

\section{Teknik Analisa Data}

Penelitian ini bersifat deskriptif dengan menggunakan analisa kuantitatif, yakni penelitian dilakukan dengan menganalisa dan menjelaskan proses perencanaan dan pengendalian kredit pada PT. Bank Perkreditan Rakyat Batang Tarusan dalam mengantisipasi kemungkinana terjadinya kredit macet.

\section{HASIL DAN PEMBAHASAN}

\section{Perencanaan Kredit Pada PT. BPR Batang Tarusan}

PT. BPR Batang Tarusan menyusun rencana kredit untuk satu tahun yang dilakukan sekali dalam setahun setiap bulan Desember dengan membuat anggaran kredit yang lebih terperinci untuk setiap triwulan melalui prosedur dan langkah-langkah yang telah ditetapkan dengan mempertimbangkan faktor-faktor dalam penyusunan anggaran kredit tersusun secara konsisten dan apabila terjadi penyimpangan dapat diketahui sendiri dan dapat dilakukan perbaikan terhadap pelaksanaan kredit tersebut.

Bagian yang menyusun rencana pemberian kredit pada PT. BPR Batang Tarusan di bidang Account Officer, kemudian setelah permohonan kredit disetujui oleh bagian 
Adm Kredit untuk diproses. Perencanaan kredit pada PT. BPR Batang Tarusan disusun berdasarkan pelaksanaan kredit masa lalu, hal ini disebabkan oleh berbagai faktor. Keadaan ini mencerminkan bahwa sebenarnya perencanaan kredit yang disusun oleh PT. BPR Batang Tarusan bersifat fleksibel.

Ada beberapa macam kredit yang diberikan oleh PT. BPR Batang Tarusan, dimana berdasarkan jenis kredit adalah sebagai berikut :

1. Kredit Installment (Kredit Cicilan)

Adalah kredit yang diberikan kepada debitur dan pembayarannya dicicil tiap-tiap bulan (angsuran pokok tambah harga) dalam jumlah yang sama dengan jangka waktu dua tahun.

a. Kredit modal kerja, adalah jenis kredit yang digunakan atau diarahkan untuk sektor industry, perdagangan serta sektor-sektor lainnya yang dipandang perlu.

b. Kredit investasi, adalah jenis kredit yang diberikan untuk membiayai kebutuhan modal yang bersifat pembelian atau penambahan barang modal, kredit ini diarahkan untuk pengusaha industry dan jasa.

c. Kredit konsumsi

\section{Kredit Regular}

Yaitu kredit yang diberikan kepada debitur dan pembayaran pokok atas pinjaman diangsur satu kali dalam sebulan atau waktu yang sesuai dengan perjanjian, sedangkan bunga pinjaman dibayar setiap bulannya.

Kredit regular terdiri dari :

a. Kredit modal kerja

b. Kredit investasi

c. Kredit konsumsi

\section{Sumber-Sumber Dana}

Sebagai lembaga keuangan, dana merupakan persoalan utama bagi bank karena tanpa ana yang cukup bank tidak akan bisa melakukan kegiatan apapun. Dana tersebut tidaklah berasal dari bank itu sendiri melainkan berasal dari pihak lain.

Secara garis besar sumber dana pada PT. BPR Batang Tarusan berasal dari :

1. Dana pihak pertama

Dana ini merupakan dana yang dimiliki oleh bank atau modal sendiri yang dapat digunakan untuk memberikan kredit

2. Dana pihak kedua

Dana pihak kedua ini merupakan dana pinjaman yang berasal dari pihak luar bank.

3. Dana pihak ketiga

Dana yang dihimpun dari masyarakat, ini merupakan sumber dana yang paling utama dalam memberikan kredit.

\section{Dasar-dasar Perncanaan Kredit}

Alat perencanaan kredit pada PT. BPR Batang Tarusan adalah anggaran, dan anggaran ini sekaligus untuk mengendalikan kredit tersebut. Anggaran kredit pada PT. BPR Batang Tarusan disusun berdasarkan peramalan/forecasting. Peramalan itu menyangkut masa yang akan datang dan oleh karena itu dipengaruhi pemerintah dan sebagaimya.

Peramalan adalah suatu cara untuk mengukur dan menaksir kondisi masyarakat pada masa yang akan datang. Pengukuran dapat dilakukan secara kuantutatif dan kualitatif. Pengukuran secara kuantitatif biasanya menggunakan metode statistic dan matematika, 
sedangkan pengukuran secara kualitatif biasanya menggunakan pendapat. Masingmasing cara tersebut mempunyai kelemahan-kelemahan dan oleh kerena itu dalam menggunakannya digunakan cara metode analisa yang ilmiah dengan pendapat pribadi. Dasar penyusunan anggaran kredit pada PT. BPR Batang Tarusan adalah pelaksanaan dari kredit itu pada masa lalu (past performance) dan faktor-faktor yang akan dipertimbangkan dalam penyusunan anggaran kredit. Oleh kerena itu dasar penyusunan anggaran kredit tersebut selalu berubah. Keadaan ini mencerminkan bahwa sebenarnya anggaran yang disusun oleh PT. BPR Batang Tarusan adalah anggaran fleksibel. Hal ini sesuai dengan hasil yang dicapai pada masa lalu dan pertimbangan kondisi pada masa yang akan datang.

\section{Tujuan Perencanaan Kredit}

Perencanaan kredit pada PT. BPR Batang Tarusan dapat digunakan untuk mengidentifikasi kegiatan perkreditan sekarang yang akan mempengaruhi hasil dimasa yang akan datang. Untuk memperkirakan masa yang akan datang, maka dapat dibuat suatu perencanaan dengan tujuan sebagai berikut :

1. Untuk meningkatkan kepekaan organisasi terhadap seluruh lingkungan social, ekonomi, politik, teknologi dan kompetitif sebagai factor eksternal yang akan mempengaruhi realisasi kredit.

2. Untuk memperkecil resiko ketidakpastian dalam mencapai tujuan dengan cara fakta-fakta yang lebih rasional di dalam prosedur pengambilan keputusan pemberian kredit.

3. Untuk mendorong penyusunan konsepsi yang terkoordinir. Perencanaan merupakan kekuatan untuk menyatukan setiap kepentingan dalam unit-unit menjadi kepentingan bersama yang tersusun dengan baik.

4. Untuk mencari ukuran prestasi perusahan di masa yang akan datang dengan melihat jalannya dengan melihat jalannya perusahaan berdasarkan realisasi kredit.

5. Untuk mengendalikan tindakan bawahan

Dengan perencanaan kredit manajemen dapat melihat tindakan bawahan terhadap hasil kerja yang dicapai berdasarkan kredit yang telah dibuat.

\section{Proses \& Langkah-langkah Dalam Penyusunan Anggaran Kredit}

\section{Proses Penyusunan Perencanaan Kredit}

Anggaran kredit dibuat oleh Direksi yang bekerja sama dengan seluruh pihak yang terdapat pada bank. Dalam proses penyusunan anggaran kredit terdapat beberapa tingkatan yang harus dilalui oleh direksi sampai anggaran tersebut disetujui untuk dilaksanakan, yaitunya :

1. Direksi dan karyawan

Pada tingkatan ini direksi bekerja sama dengan karyawan untuk mengumpulkan seluruh data yang berkaitan dengan kredit. Hal ini dilakukan kerena yang melaksanakan kegiatan operasional adalah karyawan sehingga mereka lebih mengetahui secara langsung kegiatan operasional yang dilakukan pada bank.

2. Direksi dan direksi

Pada tingkatan ini seluruh direksi mengadakan rapat untuk membahas anggaran kredit yang telah disusun apakah anggaran tersebut dapat dilanjutkan atau dilakukan perubahan kembali.

3. Direksi dan dewan komisaris 
Pada tingkatan ini direksi mengadakan pertemuan dengan dewan komisaris untuk membahas mengenai anggaran kredit yang dibuat, tujuan yang akan dicapai dan strategi untuk mencapai tujuan tersebut agar mendapatkan persetujuan atas anggaran kredit yang dibuat sehingga dapat dilaksanakan.

\section{Langkah-Langkah Penyusunan Anggaran Kredit}

Tujuan utama perusahaan adalah mempertahankan kelangsungan hidup dengan jalan berusaha mencapai laba dari penggunaan sumber-sumber dana yang dimiliki. Tujuan perusahaan itu akan dapat dicapai apabila fungsi mnajemen dapat dijalankan sebaik mungkin. Dalam melaksanakan fungsi tersebut biasanya manajer menggunakan alat yang disebut anggaran. Untuk melaksanakan kegiatan perkreditan terlebih dahulu dibuat anggaran kredit. Adapun langkah-langkah dalam penyusunan anggaran kredit adalah:

1. Penanggung jawab adalah pimpinan

Bagian pembukuan membuat anggaran kredit berdasarkan pengarahan dari pimpinn, setelah dahulu meminta data bagian kredit. Anggaran kredit yang disusun bagian pembukuan didasarkan pada realisasi anggaran kredit selama tiga tahun terakhir dan pertimbanhan kondisi-kondisi pada masa yang akan datang.

2. Anggaran kredit yang telah disusun diuji kembali kebenarannya. Hal ini berguna untuk menghindari adanya perbedaan antara satu kegiatan dengan kegiatan lainnya.

3. Kemudian draf anggaran kredit disampaikan kepada pimpinan

4. Setelah melalui negosiasi atau rapat anggaran kredit yang telah ditetapkan dan dipelajari kemudiang anggaran tersebut disetujui oleh pimpinan.

\section{Metode Least Square / Metode Jumlah Kuadrat Terkecil}

Analisis trend merupakan suatu metode analisis yang ditujukan untuk melakukan suatu estimasi atau peramalan pada masa yang akan datang. Untuk melakukan peramalan dengan baik maka dibutuhkan berbagai macam informasi (data) yang cukup banyak dan diamati dalam periode waktu yang relatif cukup panjang, sehingga dari hasil analisis tersebut dapat diketahui sampai berapa besar fluktuasi yang terjadi dan faktor-faktor apa saja yang mempengaruhi terhadap perubahan tersebut. Secara teoristis, dalam analisis time series yang paling menentukan adalah kualitas atau keakuratan dari informasi atau data-data yang diperoleh serta waktu atau periode dari data-data tersebut dikumpulkan.

Jika data yang dikumpulkan tersebut semakin banyak maka semakin baik pula estimasi atau peramalan yang diperoleh. Berdasarkan pada penjelasan diatas maka perkiraan untuk total penyaluran kredit pada PT. BPR Batang Tarusan pada tahun 2011 dapat diketahui.

\begin{tabular}{|c|c|c|c|c|}
\hline Tahun & $\mathbf{Y}$ & $\mathbf{X}$ & $\mathbf{X}^{\mathbf{2}}$ & $\mathbf{X Y}$ \\
\hline 2007 & 3.798 .337 & -2 & 4 & -7.596 .674 \\
2008 & 4.599 .423 & -1 & 1 & -4.599 .423 \\
2009 & 5.733 .408 & 1 & 1 & 5.733 .408 \\
2010 & 6.208 .965 & 2 & 4 & 12.417 .930 \\
\hline Total & $\mathbf{2 0 . 3 4 0 . 1 3 3}$ & $\mathbf{0}$ & $\mathbf{1 0}$ & $\mathbf{5 . 9 5 5 . 2 4 1}$ \\
\hline
\end{tabular}




$$
\begin{aligned}
& \mathrm{a}=\sum_{\mathrm{n}}^{\sum \mathrm{Y}}=\frac{20.340 .133}{4}=5.085 .033,25 \\
& \mathrm{~b}=\frac{\sum \mathrm{XY}}{\sum \mathrm{X}^{2}}=\frac{20.340 .133}{10}=595.524,1
\end{aligned}
$$

Sehingga persamaan trend metode least square :

$\mathrm{Y}=5.085 .033,25+595.524,1(\mathrm{X})$

Forecast penjualan untuk tahun 2011adalah :

$$
\begin{aligned}
\mathrm{Y} & =5.085 .033,25+595.524,1(3) \\
& =5.085 .033,25+1.786 .572,3 \\
& =6.871 .605,55 \\
& =6.871 .606
\end{aligned}
$$

Berdasarkan perhitungan diatas yang menggunakan metode least square maka total pemberian kredit menurut sektor ekonomi untuk tahun 2011 diperkirakan senilai Rp. 6.871.606,-

\section{Pengendalian Kredit}

PT. BPR Batang Tarusan menyusun anggaran kredit untuk merencanakan dan mengendalikan kredit. Hal ini dilakukan agar kredit yang diberikan oleh PT. BPR Batang Tarusan dapat berhasil dan berdaya guna. Dengan adanya anggaran kredit maka pengendalian akan mudah dilaksanakan kerena didalam anggaran itu telah ditetapkan target yang hendak dicapai. Banyak yang diperoleh dengan pengendalian kredit melalui anggaran, disamping merupakan pedoman dalam

pemberian kredit dapat pula digunakan untuk mengukur tingkat keberhasilan dari PT. BPR Batang Tarusan tersebut.

Pengendalian kredit oleh PT. BPR Batang Tarusan mutlak harus dilaksanakan karena dalam menjalankan usahanya menggunakan dana pihak ke tiga. Tanpa pengendalian yang baik terhadap penyaluran kredit yang diberikan maka akan terjadi kemacetan dalam penarikan kredit sehingga akan merugikan PT. BPR Batang Tarusan itu sendiri. Agar kredit yang diberikan tidak mengalami kemacetan maka sebelum kredit diberikan kepada nasabah PT. BPR Batang Tarusan melakukan seleksi terhadap nasabah atau permohonan kredit yang masuk dengan analisa 5C atau sering disebut dengan istilah 6C (Character, Capacity, Capital, Collateral, Condition of Economic, dan Constrain), 5P (Party, Purpose, Payment, Profitability, dan Protection) serta 3R (Return, Repayment, dan Risk Bearing Ability).

Dan sesudah kredit diberikan kepada nasabah pengendalian terus dilakukan oleh pihak bank sampai kredit yang diberikan tersebut dilunasi oleh nasabah. Pengendalian yang dilakukan oleh PT. BPR Batang Tarusan setelah kredit diberikan antara lain :

1. Pengendalian melalui rekening nasabah

Pengendalian melalui rekening nasabah dilakukan dengan cara memantau atau mengamati perkembangan dari rekening (bank statement) nasabah yang bersangkutan. Hal ini dapat dilihat dari setiap periode pembayaran angsuran beserta bunga pinjamam dan aliran kas masuknya. Dengan pengendalian ini pihak bank dapat melihat lancar atau tidaknya kredit nasabah. Apabila rekening nasabah dirasa kurang lancar maka pihak bank dapat menghubungi nasabah dan melakukan diskusi atau mencari informasi melalui monitoring.

2. Pengendalian melalui monitoring 
Pengendalian melalui monitoring ini dilakukan dengan cara pihak bank mengumpulkan informasi tentang nasabah, dimana informasi ini berasal dari informasi luar bank (ekstern) dan informasi dalam bank (intern) .

1) Informasi dari luar bank antara lain :

a. Melakukan kunjungan pada usaha nasabah

b. Meminta laporan realisasi kerja dan stock dari usaha nasabah

c. Meminta laporan lainnya yang dianggap perlu

2) Informasi dari dalam bank antara lain :

a. Meneliti mutasi keuangan dan rekening nasabah

b. Meneliti buku-buku pembantu kredit nasabah

c. Meneliti buku pembayaran kredit nasabah dengan membandingkan jumlah debet dan kredit direkening nasabah pada beberapa bulan yang telah berjalan.

3. Pengendalian melalui kunjungan rutin secara mendadak

Pendendalian ini dilakukan dengan cara mengunjungi atau memeriksa langsung kelapangan. Tujuan pengendalian ini adalah :

1) Untuk meneliti secara langsung melalui wawancara tentang aktivitas perusahannya.

2) Untuk memeriksa kebenaran dari data dan membandingkannya dengan keadaan secara fisik

3) Memberikan saran-saran kepada nasabah apabila ada masalah yang dihadapi

4) Mendidik nasabah untuk menyampaikan laporan kepada bank sesuia dengan kenyataan yang sebenarnya

\section{Faktor Yang Dipertimbangkan Dalam Menyusun Perencanaan Dan Pengendalian} Kredit Dengan Menggunakan Anggaran

Faktor yang perlu dipertimbangkan dalam menyusun anggaran kredit dan pengendalian kredit adalah sebagai berikut:

1. Kemana dan apa tujuan dari PT. BPR Batang Tarusan

2. Tujuan PT. BPR Batang Tarusan adalah mengumpulkan dana dari masyarakat guna dimanfaatkan untuk perbaikan ekonomi rakyat dan pembangunan ekonomi bangsa

3. Kedudukan PT. BPR Batang Tarusan dalam system perbankan Indonesia

4. Situasi perekonomian dan perdagangan

5. Realisasi pemberian kredit

6. Posisi keuangan PT. BPR Batang Tarusan

7. Persaingan dengan bank-bank atau lembaga keuangan lainnya

8. Kebijakan pemerintah

9. Kemampuan dalam mengelolah aktivitas perkreditan

\section{Analisa Terhadap Perencanaan dan Pengendalian Kredit Pada PT. BPR Batang Tarusan}

PT. BPR Batang Tarusan telah menyusun perencanaan kredit jangka pendek yang dilakukan sekali dalam setahun pada bulan Desember dengan membuat anggaran kredit yang lebih terperinci untuk setiap triwulan melalui prosedur dan langkah-langkah yang telah ditetapkan dengan mempertimbangkan factor-faktor dalam penyusunan anggaran kredit sehingga anggaran kredit tersusun secara konsisten dan apabila terjadi penyimpangan dapat diketahui sedini mungkin dan dapat dilakukan perbaikan terhadap pelaksanaan kredit tersebut. Perencanaan kredit jangka pendek ini belum memadai untuk dapat melaksanakan kegiatan perkreditan kerena rencana yang disusun hanya untuk jangka pendek saja tanpa menyusun perencanaan jangka panjang. 
Perencanaan jangka panjang disusun untuk jangka waktu lima tahun sampai dua puluh tahun yang merupakan satu kesatuan yang utuh dari rencana-rencana perusahaan secara keseluruhan meliputi perencanaan strategi dan perencanaan operasional. Perencanaan strategi disusun dan digunakan untuk menentukan dan mencapai tujuan organisasi sedangkan perencanaan operasional memberikan secara terperinci bagaimana rencanarencana strategi akan dicapai terdiri dari rencana sekali pakai (program, proyek, dan anggaran), dan rencana tetap (kebijakasanaan dan standar prosedur).

Perencanaan kredit pada PT. BPR Batang Tarusan disusun berdasarkan realisasi anggaran kredit selama tiga tahun terakhir dan pertimbangan kondisi-kondisi pada masa yang akan datang. Keadaan ini mencerminkan bahwa anggaran yang disusun oleh PT. BPR Batang Tarusan adalah anggaran fleksibel.

Tabel 3

Realisasi Anggaran Pemberian Kredit (dalam Ribuan Rupiah)

\begin{tabular}{|c|c|c|c|}
\hline Tahun & Anggaran & Realisasi & Penggunaan \\
\hline 2007 & 3.538 .648 & 3.798 .337 & $100 \%$ \\
\hline 2008 & 5.360 .025 & 4.599 .423 & $85.81 \%$ \\
\hline 2009 & 5.959 .967 & 5.733 .408 & $96.20 \%$ \\
\hline 2010 & 7.594 .701 & 6.208 .965 & $81.75 \%$ \\
\hline
\end{tabular}

Sumber : PT. BPR Batang Tarusan

Dari tabel diatas dapat dilihat bahwa dari tahun 2007 realisasi pemberian kredit dari yang telah dianggarkan pencapaiannya sebesar 100\%, sementara ditahun 2008 penyaluran kredit mengalami penurunan sebesar $85.81 \%$, tahun 2009 penyaluran kredit mengalami kenaikan sebesar 96.20\% dan pada tahun 2010 penyaluran kredit mengalami penuruan sebesar $81.75 \%$.

Dengan adanya penyimpangan dan realisasi kredit PT. BPR Batang Tarusan akan melakukan perbaikan terhadap pelaksanaan kegiatan perkreditan dan untuk memperkecil penyimpangan yang terjadi PT. BPR Batang Tarusan melakukan pengendalian kredit agar kredit yang diberikan tidak mengalami kemacetan maka sebelum kredit diberikan kepada nasabah PT. BPR Batang Tarusan melakukan seleksi terhadap permohonan kredit yang masuk dengan analisa $5 \mathrm{C}$ atau $6 \mathrm{C}$ dan $5 \mathrm{P}$ serta $3 \mathrm{R}$. Kemudian setelah kredit diberikan bank melakukan pengendalian melalui rekening nasabah, monitoring, dan kunjungan rutin secara mendadak.

Apabila terjadi kredit macet maka debitur akan melakukan sanksi hukum sesuai dengan persetujuan yang telah disepakati sebelumnya, misalnya menyita agunan/jaminan kredit dari debitur itu sendiri. Pengendalian dilaksanakan dengan meneliti dan melakukan serangkaian prosedur dan persyaratan yang harus diikuti calon debitur.

\section{KESIMPULAN DAN SARAN}

Berdasarkan uraian-uraian dari bab terdahulu maka pada bab terakhir ini penulis akan mengemukan beberapa kesimpulan yang merupakan inti dari penelitian ini, antara lain :

1. Perencanaan Kredit

Dari analisa yang dilakukan maka dapat dikemukakan hal-hal sebagai berikut:

a. PT. BPR Batang Tarusan telah menyusun rencana kredit jangka pendek (satu tahun) untuk menunjang kelancaran aktivitasnya dibidang perkreditan yang dituangkan dalam bentuk anggaran kredit sebagai salah satu alat perencanaan kredit tanpa menyusun rencana jangka panjang yang merupakan satu kesatuan yang utuh dari rencana perusahaan secara keseluruhan yang meliputi perencanaan strategi dan perencanaan operasional. 
b. PT. BPR Batang Tarusan telah menetapkan jadwal penyusunan anggaran setiap bulan Desember dengan cara menyusun rencana kredit lebih terperinci sehingga penyimpangan dapat diketahui sedini mungkin dan dapat dilakukan perbaikan terhadap pelaksanaan kredit tersebut.

c. Dasar penyusunan anggaran kredit pada PT. BPR Batang Tarusan adalah past performance yaitu pelaksanaan kredit pada masa lalu dan peramalan pada masa yang akan datang maka dipengaruhi oleh beberapa factor sehingga anggaran kreditnya bersifat fleksibel.

d. Dalam penyusunan perencanaan anggaran kredit PT. BPR Batang Tarusan talah melalui proses dan langkah-langkah yang cukup baik

e. Perencanaan kredit yang dilakukan PT. BPR batang Tarusan digunakan untuk mengidentifikasikan kegiatan perkreditan sekarang yang akan mempengaruhi hasil dimasa yang akan datang.

f. Pelaksanaan perencanaan anggaran kredit pada PT. BPR Batang Tarusan belum berfungsi secara efektif. Hal ini dapat dilihat dari realisasi kredit yang terjadi jika dibandingkan dengan anggaran kredit sering terjadi penyimpangan yangdisebabkan oleh beberapa factor.

2. Pengendalian Kredit

a. Pengendalian kredit dilakukan dengan menggunakan anggaran dan analisa permohonan kredit serta pengendalian sesudah kredit diberikan.

b. Pengendalian kredit melalui anggaran yaitu membandingkan anggaran kredit dengan realisasinya sehingga penyimpangan dapatdiketahui sedini mungkin dan dapat dilakukan perbaikan terhadap pelaksanaan kredit tersebut.

c. Pengendalian kredit dalam menganalisa permohonan kredit dapat dilakukan dengan menggunakan prinsip 5C, 5P dan 3R.

d. Pengendalian setelah kredit diberikan dapat dilakukan melalui rekening nasabah, monitoring, dan kunjungan rutin secara mendadak.

e. Pengendalian kredit terhadap nasabah dilakukan dengan meneliti atau menganalisa dan melakukan serangkaian prosedur serta persyaratan yang harus diikuti oleh calon debitur.

f. PT. BPR Batang Tarusan melakukan pengendalian kredit bertujuan untuk mengurangi terjadinya kredit macet.

g. Jika terjadi kredit macet maka debitur akan diberikan sanksi hukuman sesuai dengan perjanjian yang telah disepakati.

\section{DAFTAR PUSTAKA}

Afriyeni, A., \& Putra, Y. E. (2019). Analisis Faktor-Faktor Yang Mempengaruhi Tingkat Pengembalian Kredit Usaha Rakyat (KUR) PT. Bank Rakyat Indonesia (BRI) Unit Talang Cabang Solok. https://doi.org/10.31219/osf.io/crfpg

Afriyeni, A., \& Susanto, R. (2019). Analisis Pengaruh Pemberian Kredit Terhadap Loan To Deposit Ratio dan Dampaknya Pada Pendapatan (Studi Pada PT BPR Lengayang Pesisir Selatan). https://doi.org/10.31219/osf.io/mnbtv

Alanshari, F., \& Marlius, D. (2018). Prosedur Pemberian Kredit KPR Pada PT. Bank Tabungan Negara (Persero) TBK Cabang Pembantu Bukittinggi. https://doi.org/10.31227/osf.io/rsfhc 
Amelia, L., \& Marlius, D. (2018). Pengendalian Kredit Dalam Upaya Menciptakan Bank Yang Sehat Pada PT. Bank Pembangunan Daerah Sumatera Barat Cabang Utama Padang. https://doi.org/10.31227/osf.io/kpc64

Andriani, B., \& Susanto, R. (2019). Pengawasan Kredit PT. Bank Perkreditan Rakyat (BPR) Ophir Pasaman Barat. https://doi.org/10.31219/osf.io/aunvc

Baiya, \& Fernos, J. (2019). Analisis Faktor-Faktor Penyebab Kredit Macet Pada Bank Nagari Cabang Siteba. https://doi.org/10.31227/osf.io/4xuks

Darmawanto, \& Fernos, J. (2019). Prosedur Pemberian Kredit Pada Bank Nagari Cabang Sijunjung. https://doi.org/10.31227/osf.io/psqfy

Firmansyah, A., \& Fernos, J. (2019). Analisis Kredit Bermasalah Dilihat Dari Standar Non Performing Loan (NPL) Pada PT. Bank Perkreditan Rakyat (BPR) Prima Mulia Anugrah Cabang Padang. https://doi.org/10.31227/osf.io/gcj94

Febriansyah, I., \& Afriyeni, A. (2019). Penyelesaian Kredit Bermasalah PT. Bank Pembangunan Daerah (BPD) Sumbar Cabang Alahan Panjang Kabupaten Solok. https://doi.org/10.31219/osf.io/vutmj

Ikbal, M., \& Marlius, D. (2017). Pengaruh Jumlah Taksiran Dan Uang Pinjaman Terhadap Laba Bersih Pada PT. Pegadaian (UPC) Gurun Laweh. https://doi.org/10.31227/osf.io/uch4a

Mulyadi, Drs, MSc. 1993. Sistem Akuntansi. Penerbit, BP-STIEYKPN, Yogyakarta. Edisi ketiga

Sinungan, Muchdarsyah. 2001. Dasar-dasar dan Teknik Manajemen Kredit. Bumi Aksara, Jakarta.

Muljono,Teguh, Pudjo. 1994, Manajemen Perbankan komersial, BPFE, Yogjakarta.

Munawir.1993. Analisa Laporan Keuangan, Liberty, Yogjakarta.

Orlando, A., \& Susanto, R. (2019). Mekanisme Pencairan Kredit Usaha Rakyat Pada PT. Bank Rakyat Indonesia Unit Lubuk Buaya. https://doi.org/10.31219/osf.io/zuv2y

Pratama, D., \& Fernos, J. (2019). Prosedur Pelaksanaan Kredit Usaha Rakyat (KUR) Pada PT. Bank Nagari Cabang Padang. https://doi.org/10.31227/osf.io/ag68j

Sekaran, U. (2003). Research Methods for Bussines a Skill Building Approach. Four Edition. John Willey and Son, inc.

Siamad.1995. Dasar-dasar Manajemen Keuangan, Ananda, Yogjakarta.

Sugiharto, SE, MBA. 2006, Credit Management Handbook, PT. Raja Grafindo.Persada, Jakarta 
Sugiyarso. 2005. Manajemen Keuangan, Yogjakarta.

Suyatno. 1997. Kelembagaan Perbankan, BPFE, Yogjakarta.

Weston J. Fred dan E.F Brighman. 1994. Dasar-dasar Manajemen Keuangan. Edisi 9 Erlangga, Jakarta.

Widayati, R. (2019). Penerapan Sistem Pembagian Pendapatan Pada Bank Mudharabah Nagari Syariah Cabang Padang. https://doi.org/10.17605/OSF.IO/BC3R5

Widayati, R. (2019). Penyelesaian Kredit Bermasalah Pada PT. Bank Perkreditan Rakyat (BPR) Nagari Kasang. https://doi.org/10.17605/OSF.IO/D4MF3

Widayati, R. (2019). Pelaksanaan Prinsip Kehati-Hatian Dalam Pemberian Kredit Konsumtif Pada Bank Nagari Cabang Siteba. https://doi.org/10.17605/OSF.IO/FZVXR

Widayati, R. (2019). Aktivitas Pemberian Kredit Komersil Pada Bank Nagari Cabang Sijunjung. https://doi.org/10.17605/OSF.IO/QTVZ9

Widayati, R. (2019). Pelaksanaan Kredit Pada Bank Perkreditan Rakyat LPN Pasar Baru Durian Sawahlunto. https://doi.org/10.17605/OSF.IO/5HPAB

Widayati, R. (2019). Upaya Penanganan Kredit Bermasalah Pada Bank Nagari Cabang Utama Padang. https://doi.org/10.17605/OSF.IO/YJ3KN

Widayati, R. (2019). Aktivitas Pemberian Kredit Usaha Pada PT. Bank Perkreditan Rakyat Batang Kapas. https://doi.org/10.17605/OSF.IO/EDPN4

Yasman, R., \& Afriyeni, A. (2019). Prosedur Pemberian Kredit Pada PT. Bank Pekreditan Rakyat (BPR) Jorong Kampung Tangah (JKT) Pariaman Cabang Padang. https://doi.org/10.31219/osf.io/c5ufr 